\title{
Care seeking behavior of people with common mental disorders in São Paulo-Brazil
}

\author{
Gustavo de Brito Venâncio dos Santos ${ }^{1 *}$ [D, Moisés Goldbaum², Chester Luiz Galvão César ${ }^{3}$ \\ and Reinaldo José Gianini ${ }^{1}$
}

\begin{abstract}
Background: Mental health in developing countries is a keen area for improvements. Epidemiological research in this field helps to reinforce information, generate hypothesis and guide police makers. This study intends to analyze patterns of care seeking among cases of common mental disorders (CMD) in São Paulo city in 2015.

Methods: The data is from the population-based survey ISA-Capital 2015 and the screening for common mental disorders follows the Self-reporting questionnaire (SRQ-20). The study analyses care seeking according to sociodemographic and health conditions.

Results: The prevalence of CMD was 19.7\% (95\% Cl 18.2-21.4\%). There was a higher prevalence of CMD among who sought care in last 30 days (25.4\%). Among CMD cases, care seeking presented significant different prevalence ratio (PR) for: women (PR 1.13; 95\% Cl 1.05-1.2); age 60 years or more (PR 1.13; 95\% Cl 1.05-1.22) and 30-44 years (PR 1.10; 95\% Cl 1.01-1.2); brown skin (PR 0.92; 95\% Cl 0.86-0.97); single or divorced (PR 0.93; 95\% Cl 0.89-0.99); unemployed (PR 1.06; 95\% Cl 1.01-1.12); last 15 days referred morbidity (PR 1.3; 95\% Cl 1.2-1.34); physical disability (PR 1.11; $95 \% \mathrm{Cl}$ 1.06-1.18); and chronic disease (PR 1.15; 95\% Cl 1.07-1.24).
\end{abstract}

Conclusion: Identifying vulnerable groups and developing proper public health actions is important to promote equity accessibility. Analysing care seeking behavior among people with CMD is a strong contribution.

Keywords: Care seeking, healthcare accessibility, Health equity, Mental health, Health surveys

\section{Introduction}

Mental illness is present worldwide and generates a huge social and economic impact. A new projection attributed $32.4 \%$ of years lived with disability and $13.0 \%$ of disability-adjusted life-years to the global burden of mental illness [1]. Developing countries face a high prevalence of these diseases and are not well prepared to handle them [2]. Furthermore, an association between poverty and mental health diseases in these nations has been suggested [3].

\footnotetext{
*Correspondence: venanciogustavodebrito@hotmail.com

${ }^{1}$ Medical and Health Sciences School-PUCSP, Sorocaba, Brazil

Full list of author information is available at the end of the article
}

Goldberg and Huxley introduced the term Common Mental Disorders (CMD) to describe a set of somatic, depressive and anxiety symptoms that causes important mental impairment [4]. Researches and practitioners have been accessed it through the self-reporting questionnaire (SRQ-20), which is a screening tool for mental disorders recommended by the world health organization to be used in primary care of developing countries [5].

In Brazil, measures of common mental disorders prevalence vary from 17 to $35 \%$ [6-11]. The importance of these studies resides on the direction for public health polices and recognition of possible risk factors and vulnerable populations.

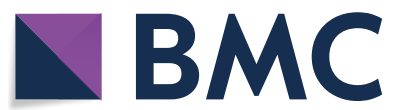

(c) The Author(s) 2020. This article is licensed under a Creative Commons Attribution 4.0 International License, which permits use, sharing, adaptation, distribution and reproduction in any medium or format, as long as you give appropriate credit to the original author(s) and the source, provide a link to the Creative Commons licence, and indicate if changes were made. The images or other third party material in this article are included in the article's Creative Commons licence, unless indicated otherwise in a credit line to the material. If material is not included in the article's Creative Commons licence and your intended use is not permitted by statutory regulation or exceeds the permitted use, you will need to obtain permission directly from the copyright holder. To view a copy of this licence, visit http://creativeco mmons.org/licenses/by/4.0/. The Creative Commons Public Domain Dedication waiver (http://creativecommons.org/publicdomain/ zero/1.0/) applies to the data made available in this article, unless otherwise stated in a credit line to the data. 
Vulnerability patterns and social determinants are parameters to achieve health equity, mainly in mental health [12]. Consequently, the population who needs more assistance for facing social and health inequalities can be prioritized. One way to assure this condition is through healthcare accessibility.

The aim of this research was to investigate care seeking behavior of people with common mental disorders who lived in São Paulo city urban area in the year of 2015.

\section{Methods}

The analysis was made through data from São Paulo city survey ISA-Capital 2015 [13]. It is the third edition of a survey population-based. Participants were residents from the urban area of São Paulo city. Census tracts were clusters and households were primary sample units. Health administrative regions (North, Midwest, Southeast, South and East) were the strata of the county; in each region, based on the 2010 demographic census were elected 30 tracts. Following domains formed the ISACapital 2015 sample: 12-19 years (males and females), $20-59$ years (males), $20-59$ years (females) and $\geq 60$ years (males and females). The sample was calculated based on an estimate of $50 \%$ prevalence, with 0.10 error, considering a level of $95 \%$ of confidence and an effect design of 1.5. In this research 5942 households were sampled; among these, 5469 were visited. To accomplish the objectives of our research a total of 4043 individuals were interviewed, 3732 aged 15 years old or more, with 3619 people being classified according to the self-reporting questionnaire (SRQ20).

The SRQ-20 contains 20 simple "yes or no" questions and is related to the block E on ISA-Capital 2015, classified the common mental disorder (CMD). This questionnaire was validated in Brazil in 1986 by Mari and Williams [14] in a study that compared it to the standardized psychiatric interview. The sensitivity, taking into consideration the cutting-point of $5 / 6$ for men and $7 / 8$ for women, was $83 \%$ and specificity $80 \%$, being a good indicator of morbidity. A more recent validation research conducted in 2008 by Gonçalves, Stein and Kapczinski [15] showed a sensitivity of $86.33 \%$ and specificity of $89.31 \%$, considering the cutting-point of $7 / 8$ (compared to the structured clinical interview for DSM-IV-TR as gold standard). The discriminatory power was 0.91 and the Cronbach's alpha 0.86 . Moreover, Scafuza et al. in 2009 [16] tested the SRQ-20 validity in the elderly population finding the cutting-point $4 / 5$ with the best sensitivity and specificity for both genders. Therefore, in this research, the cutting points to establish the presence of CMD were: 64-years-old or younger men $=6$ or more positive answers; 64-years-old or younger women $=8$ or more positive answers [14]; and 65-year-old or older men or women $=5$ or more positive answers [16].

The sociodemographic variables were sex, age group, skin color, marital status, education, working status, and income. The health variables were last 15 days referred morbidity, physical disability, mental/intellectual disability, chronic diseases and headache. The variable related with health accessibility were last 30 days care seeking.

First it was performed the care seeking frequency distribution according to CMD cases. The statistical significance of the prevalence ratio in each observation was evaluated through Chi square test corrected by the Satterthwaite's approximate F test. Second, the analysis verified the association between the sociodemographic or health condition and care seeking in CMD cases. Poisson regression was used for calculating prevalence ratio (PR) and $95 \%$ confidence interval.

The analysis took into consideration the stratification, weighted and cluster sampling process. The statistical analysis employed STATA 11 software.

The ethics committee of PUC-SP, Sorocaba Campus, approved this research (CAAE 66296917.0.0000.5373).

\section{Results}

Among the 3619 people sampled, 780 had a positive screening for CMD. Thus, the prevalence of CMD considering sample weights is $19.7 \%(95 \% \mathrm{CI}=18.2-21.4 \%)$. The description of each question on SRQ20, together with the numbers of positive answers among individuals with CMD, are listed in Table 1.

Those who sought care in the last 30 days presented a higher prevalence of CMD (25.4\%). Although the CMD prevalence was slightly larger for whose answered yes for availability in the last care seeking, there was no significant difference (Table 2). CMD cases had been successful in $96.8 \%$ when sought for care.

The analysis of "last 30 days care seeking" among CMD cases showed higher prevalence for sex (females, $\mathrm{PR}=1.13 ; \mathrm{p}<0.001$ ); age (groups of $30-44$ years, $\mathrm{PR}=1.10 ; \mathrm{p}=0.027$ and 60 years or more, $\mathrm{PR}=1.13$; $\mathrm{p}<0.001$ ); working status (unemployed, $P R=1.06$; $\mathrm{p}=0.033$ ); last 15 days referred morbidity (yes, $\mathrm{PR}=1.3$; $\mathrm{p}=0.001$ ); physical disability (yes, $\mathrm{PR}=1.11 ; \mathrm{p}=0.001$ ); and chronic disease (yes, $P R=1.15 ; \mathrm{p}=0.001$ ). The prevalence of "last 30 days care seeking" among CMD cases showed lower for skin color (brown, $\mathrm{PR}=0.92$; $\mathrm{p}=0.007$ ); and marital status (single or divorced, $\mathrm{PR}=0.93 ; \mathrm{p}=0.017$ ). There was no significant difference of "last 30 days care seeking" for education, income, mental/intellectual disability, and headache. (Table 3). 
Table 1 Proportion of positive answers for each question of SRQ20 among individuals with CMD

\begin{tabular}{llll}
\hline Question & Description & N positive answers & $\begin{array}{c}\text { \% positive } \\
\text { answers }\end{array}$ \\
\hline 1 & Do you often have headaches? & 410 & 53.6 \\
2 & Is your appetite poor? & 356 & 45.6 \\
3 & Do you sleep badly? & 517 & 66.3 \\
4 & Are you easily frightened? & 437 & 56 \\
5 & Do your hands shake? & 277 & 35.5 \\
6 & Do you feel nervous, tense or worried? & 672 & 86.2 \\
7 & Is your digestion poor? & 341 & 43.7 \\
8 & Do you have trouble thinking clearly? & 412 & 52.8 \\
9 & Do you feel unhappy? & 594 & 76.2 \\
10 & Do you cry more than usual? & 365 & 46.8 \\
11 & Do you find it difficult to enjoy your daily activities? & 399 & 51.2 \\
12 & Do you find it difficult to make decisions? & 466 & 59.7 \\
13 & Is your daily work suffering? & 269 & 34.5 \\
14 & Are you unable to play a useful part in life? & 229 & 29.4 \\
15 & Have you lost interest in things? & 382 & 49 \\
16 & Do you feel that you are a worthless person? & 195 & 25 \\
17 & Has the thought of ending your life been on your mind? & 95 & 12.2 \\
18 & Do you feel tired all the time? & 432 & 57.4 \\
19 & Do you have uncomfortable feelings in your stomach? & 486 & 47.6 \\
20 & Are you easily tired? & & 62.3 \\
\hline
\end{tabular}

Table 2 CMD prevalence and its prevalence ratio in accordance with the healthcare accessibility. Sao Paulo, 2015

\begin{tabular}{lllll}
\hline Variable & $\begin{array}{l}\text { CMD } \\
\text { prevalence } \\
\text { (\%) }\end{array}$ & $\begin{array}{l}\text { Prevalence } \\
\text { patio }\end{array}$ & $\begin{array}{l}\text { 95\% } \\
\text { confidence } \\
\text { interval }\end{array}$ & $\mathbf{p}$ \\
\hline $\begin{array}{l}\text { Care seeking } \\
\text { Last 30 days }\end{array}$ & 25.4 & 1.49 & $1.29-1.71$ & $<0.001$ \\
More than 30 days & 17.1 & 1 & & \\
$\begin{array}{l}\text { Availability in the last care seeking } \\
\text { Yes }\end{array}$ & 20 & 1.29 & $0.84-2.00$ & 0.234 \\
No & 15.4 & 1 & & \\
\hline
\end{tabular}

\section{Discussion}

The prevalence of CMD in this study was $19.7 \%(95 \%$ CI 18.2-21.4\%). A systematic review with meta-analysis made by Steel et al. in 2014 [17] described a global CMD prevalence of $17.6 \%$ (95\% CI 16.3-18.9\%). Thus, the present results is similar with the current literature. However, studies made in rural areas tend to present higher prevalence rates when compared to urban areas, as demonstrated by Silva et al. [18] and Costa and Ludermir [19], who reveal a prevalence of $24.1 \%$ and $36 \%$ of CMD in rural areas, respectively. Therefore, studies that analyse the health care seeking behaviour of people with CMD in rural areas are important, and their results could be compared with those from our present study in order to verify if the principle of equity is present.

Those who sought care in the last 30 days (28.4\%) had a 1.49 prevalence ratio of CMD (95\% CI 1.29-1.71). The analysis showed sex, age group, skin color, marital status, working status, last 15 days referred morbidity, physical disability, and chronic disease associated with "last 30 days care seeking" among CMD cases.

The higher prevalence of CMD in those who sought health care in the last 30 days highlighted a specific demand and an opportunity to improve the diagnosis and treatment of these patients. Gonçalves and Kapczinski [20] in 2008 found that $51.1 \%$ of who sought care in a primary health unity of South Brazil were diagnosed with some psychiatric disorder. Moreover, these patients had more visits to health units in the last 12 months.

The difference between men and women about care seeking shows a common trend. Women with CMD had a 1.12 more prevalence of care seeking in the last 30 days (95\% CI 1.05-1.2) when compared with men with CMD. A study conducted in Canada and published in 2016 [21] demonstrated a gender difference in care seeking, where women reported visiting their primary care provider more frequently than men, both for physical and mental health problems. In Brazil, Pinheiro et al. [22] point out that women refer more morbidity 
Table 3 Analysis of "last 30 days care seeking" among CMD cases according to sociodemographic and health conditions. Sao Paulo, 2015

\begin{tabular}{llll}
\hline Variable & \multicolumn{3}{l}{ Last 30 days care seeking } \\
\cline { 2 - 4 }$\%$ & $\begin{array}{l}\text { Prevalence } \\
\text { ratio }\end{array}$ & $p$ & $95 \% \mathrm{Cl}$
\end{tabular}

\begin{tabular}{|c|c|c|c|c|}
\hline \multicolumn{5}{|l|}{ Sex } \\
\hline Male & 30.1 & 1 & & \\
\hline Female & 46.4 & 1.13 & $<0.001$ & $1.05-1.2$ \\
\hline \multicolumn{5}{|l|}{ Age group (years) } \\
\hline $15-29$ & 31.2 & 1 & & \\
\hline $30-44$ & 44.7 & 1.10 & 0.027 & $1.01-1.20$ \\
\hline $45-59$ & 40.6 & 1.07 & 0.106 & $0.98-1.16$ \\
\hline 60 or more & 48.6 & 1.13 & 0.001 & $1.05-1.22$ \\
\hline \multicolumn{5}{|l|}{ Skin color } \\
\hline White & 46 & 1 & & \\
\hline Black & 35.6 & 0.93 & 0.143 & $0.84-1.03$ \\
\hline Yellow or indigenous & 43.8 & 0.98 & 0.892 & $0.79-1.23$ \\
\hline Brown & 33.8 & 0.92 & 0.007 & $0.86-0.97$ \\
\hline \multicolumn{5}{|l|}{ Marital status } \\
\hline Married & 44.4 & 1 & & \\
\hline Single or divorced & 35 & 0.93 & 0.017 & $0.89-0.99$ \\
\hline Widow & 45.8 & 1 & 0.824 & $0.93-1.10$ \\
\hline \multicolumn{5}{|l|}{ Education } \\
\hline Undergraduate or more & 34.1 & 1 & & \\
\hline 9 to 11 years (high school) & 38.6 & 1.03 & 0.625 & $0.90-1.18$ \\
\hline 1 to 8 years (basic) & 42.8 & 1.06 & 0.331 & $0.94-1.21$ \\
\hline No education & 42.5 & 1.06 & 0.416 & $0.98-1.23$ \\
\hline \multicolumn{5}{|l|}{ Working status } \\
\hline Employed & 38.2 & 1 & & \\
\hline Unemployed & 46.8 & 1.06 & 0.033 & $1.01-1.12$ \\
\hline \multicolumn{5}{|l|}{ Income (minimal wage) } \\
\hline Until 1 & 36.5 & 0.98 & 0.822 & $0.84-1.14$ \\
\hline$+1-2$ & 41.3 & 1.02 & 0.806 & $0.89-1.16$ \\
\hline$+2-4$ & 41.4 & 1.02 & 0.785 & $0.95-1.16$ \\
\hline$+4-9$ & 40.2 & 1 & 0.892 & $0.89-1.15$ \\
\hline+9 & 38.9 & 1 & & \\
\hline \multicolumn{5}{|l|}{ Last 15 days referred morbidity } \\
\hline No & 28.7 & 1 & & \\
\hline Yes & 63.8 & 1.3 & $<0.001$ & $1.20-1.34$ \\
\hline \multicolumn{5}{|l|}{ Physical disability } \\
\hline No & 32.9 & 1 & & \\
\hline Yes & 48.6 & 1.11 & $<0.001$ & $1.06-1.18$ \\
\hline \multicolumn{5}{|l|}{ Mental/intellectual disability } \\
\hline No & 40.7 & 1 & & \\
\hline Yes & 47.2 & 1.05 & 0.482 & $0.91-1.19$ \\
\hline \multicolumn{5}{|l|}{ Headache } \\
\hline No & 37.9 & 1 & & \\
\hline Yes & 43.4 & 1.04 & 0.194 & $0.98-1.1$ \\
\hline \multicolumn{5}{|l|}{ Chronic disease } \\
\hline No & 24.5 & 1 & & \\
\hline
\end{tabular}

Table 3 (continued)

\begin{tabular}{lllll}
\hline Variable & \multicolumn{4}{l}{ Last $\mathbf{3 0}$ days care seeking } \\
\cline { 2 - 5 } & $\begin{array}{l}\text { Prevalence } \\
\text { ratio }\end{array}$ & $\mathbf{p}$ & $\mathbf{9 5 \%} \mathbf{C l}$ \\
\hline Yes & 43.7 & 1.15 & $<0.001$ & $1.07-1.24$ \\
\hline
\end{tabular}

and psychological problems than men and, consequentially, look more for medical services. In other Brazilian study published in 2014 that analyzed the gender difference in care seeking behavior [23] other factors were associated with the non-demand for health services, like opening-time of health care facilities and users working hours.

In United States of America, race and ethnic minorities, like Latinos, blacks and native Americans, have less accessibility to healthcare services when compared to whites [24]. In Brazil, the results of a national health survey made in 2013 [25] found that white people reported less underutilization of healthcare than no-white individuals. In our research, neither black, yellow nor indigenous individuals showed a statistical difference with "last 30 days care seeking" when compared to white individuals. However, brown individuals among CMD cases had a prevalence ratio of 0.93 (95\% CI $0.87-0.99$ ), lower than white people. The absence of significant difference according to income and education could be a good new if confirmed by future studies, and could be a positive characteristic of the Brazilian health system implemented since 1991 [24].

Single or divorced people with CMD had a slightly lower seeking behavior when compared to married ones (PR 0.93 95\%CI 0.82-0.99); this is consistent with other studies $[26,27]$. In the study published by the International Journal of Epidemiology [27], several analyses were made aiming to control possible confounding factors, besides age and sex, which affect the association between health care utilization and marital status. The conclusion was that the association remained after ruling out other possible confounding socio-demographic variables such as educational level, degree of urbanization, country of birth and religious background. However, the authors point towards the need of further investigation with the inclusion of socio-psychological variables to better understand this association. Undoubtedly, the marital status is associated with health care use and seeking behavior. It seems that the existence and maintenance of a relationship have a positive influence on the practices of self-care among individuals.

As expected, people with unfavorable health conditions, like "last 15 days referred morbidity" and chronic diseases, sought more for medical assistance. 
Faithfully, there was no difference in the prevalence of CMD considering the availability of healthcare, which may reflect an egalitarian accessibility. However, only one aspect of accessibility was measured-the availability of healthcare services. There are a lot of dimensions when considering accessibility including factors as individuallevel, practitioner-level, system-and-process-level, and resource-based or practical-level [28].

\section{Conclusion}

Given the results it is possible to identify vulnerable groups and in this way direct proper attention and further research. People who recently sought care had a higher prevalence of common mental disorders, which can serve as an alert for health practitioners. Furthermore, among people with a positive CMD screening some socioeconomic categories were associated with different care seeking behavior. This is important to understand the specific context of this population and create polices to convey healthcare considering equity.

Regarding the availability of healthcare, one indirect measure of health accessibility, CMD cases did not receive a different treatment when compared with negative CMD group. This is favourable, although should be investigated other aspects of health accessibility in further research.

Despite the sample was representative of population and a trained staff collected the data, self-referred information based the present research, which can be listed as a study limitation. Moreover, the survey study model does not allow establishing a causality. Finally, others factors besides the socio-demographic variables analysed influence the care seeking behaviour. There are individual factors (e.g. recognize the need to seeking care and have knowledge about the facilities availability) and external factors (e.g. transport, distance from healthcare service and communication) that should be considerate.

\section{Abbreviations \\ CMD: Common mental disorders; DSM-IV-TR: Diagnostic and statistical manual of mental disorders fourth edition text revision; SRQ-20: Self-reporting questionnaire (with 20 questions); PR: Prevalence ratio; PUC-SP: Pontifícia Universidade Católica de São Paulo; 95\% Cl: 95\% Confidence interval.}

\section{Acknowledgements}

Not applicable.

\section{Authors' contributions}

MG and CLGC have made substantial contributions to the conception and design of ISA-Capital 2015. RJG and GBVS have made the interpretation of data and the conception of the present article. All authors read and approved the final manuscript.

\section{Funding}

One of the authors (G.B.V.S.) received a scholarship from the CNPq to do this research as part of the scientific initiation Scholarship Program (PIBIC) for under graduation students.

\section{Availability of data and materials}

The datasets used and/or analyzed during the current study are available from the corresponding author on reasonable request.

\section{Ethics approval and consent to participate}

The ethics committee of PUC-SP, Sorocaba Campus, approved this research (CAAE 66296917.0.0000.5373).

\section{Consent for publication \\ Not applicable.}

\section{Competing interests}

The authors declare that they have no competing interests.

\section{Author details}

${ }^{1}$ Medical and Health Sciences School-PUCSP, Sorocaba, Brazil. ${ }^{2}$ Department of Preventive Medicine, University of São Paulo, Medicine School, São Paulo, Brazil. ${ }^{3}$ Department of Epidemiology, University of São Paulo, Public Health School, São Paulo, Brazil.

Received: 31 December 2019 Accepted: 16 May 2020

Published online: 24 May 2020

\section{References}

1. Vigo D, Thornicroft G, Atun R. Estimating the true global burden of mental illness. Lancet Psychiatry. 2016;3:171-8.

2. Patel V. Mental health in low- and middle-income countries. Br Med Bull. 2007;81-82:81-96.

3. Patel V, Kleinman A. Poverty and common mental disorders in developing countries. Bull World Health Organ. 2003;81:609-15.

4. Goldberg DP, Huxley P. Common mental disorders: a bio-social model common mental disorder. A bio-social Model. Tavistock: Routledge; 1992.

5. World Health Organization. Division of Mental Health. A User's guide to the self reporting questionnaire (SRQ). Geneva: World Health Organization; 1994.

6. Ludermir AB, Melo Filho DA. Living conditions and occupational organization associated with common mental disorders. Condições de vida e estrutura ocupacional associadas a transtornos mentais comuns. Rev Saude Publica. 2002;36:213-21.

7. Mendoza-Sassi RA, Béria JU. Gender differences in self-reported morbidity: evidence from a population-based study in southern Brazil. Cad Saúde Pública. 2007:23:341-6.

8. Marín-León L, Oliveira HB, Barros MBA, Dalgalarrondo P, Botega NJ. Social inequality and common mental disorders. Rev Bras Psiquiatr. 2007;29:250-3.

9. Rocha SV, Almeida MMG, Araújo TM, Virtuoso Júnior JS. Prevalence of common mental disorders among the residents of urban areas in Feira de Santana, Bahia. Prevalência de transtornos mentais comuns entre residentes em áreas urbanas de Feira de Santana, Bahia. Rev Bras Epidemiol. 2010;13:630-40.

10. Rodrigues-Neto JF, Figueiredo MFS, Faria AAS, Fagundes M. Commom mental disorders and the use of complementary and alternative medicine-population-based survey. Transtornos mentais comuns e o uso de práticas de medicina complementar e alternativa: estudo de base populacional. J Bras Psiquiatr. 2008:57:233-9.

11. Moraes Júnior EC (2010) Prevalence and risk factors for Common Mental Disorder in the urban population in metropolitan area of São Paulo, Brazil. Prevalência e fatores de risco para transtorno mental comum na população urbana da região metropolitana de Sâo Paulo. Master's degree dissertation, Botucatu Medical School, Universidade Estadual Paulista-UNESP.

12. Satcher D, Rachel SA. Promoting mental health equity: the role of integrated care. J Clin Psychol Med Settings. 2017;24:182-6.

13. Alves MCGP, Escuder MML, Goldbaum M, de Barros MBA, Fisberg RM, Cesar CLG. Sampling plan in health surveys, city of São Paulo, Brazil, 2015. Rev Saúde Pública. 2018:52:81.

14. Mari JJ, Williams P. A validity study of a psychiatric screening questionnaire (SRQ-20) in primary care in the city of Sao Paulo. Br J Psychiatry. $1986 ; 148: 23-6$. 
15. Gonçalves DM, Stein AT, Kapczinski F. Performance of the Self-Reporting Questionnaire as a psychiatric screening questionnaire: a comparative study with Structured Clinical Interview for DSM-IV-TR. Avaliação de desempenho do Self-Reporting Questionnaire como instrumento de rastreamento psiquiá. Cad Saúde Pública. 2008;24:380-90.

16. Scazufca M, Menezes PR, Vallada H, Araya R. Validity of the self reporting questionnaire-20 in epidemiological studies with older adults. Soc Psychiatry Psychiatr Epidemiol. 2009;44:247-54.

17. Steel Z, Marnane C, Iranpour C, Chey T, Jackson JW, Patel V, Silove D. The global prevalence of common mental disorders: a systematic review and meta-analysis 1980-2013. Int J Epidemiol. 2014;43:476-93.

18. da Silva AC, Vargas LS, Moraes RCC, Lucchese R, Guimarães RA, Vera I. Prevalence and factors associated with common mental disorder in rural settlers*. Prevalência e fatores associados ao transtorno mental comum em assentados rurais*. SMAD Rev eletrônica saúde Ment álcool e Drog. 2019;15:23-31.

19. da Costa AG, Ludermir AB. Common mental disorders and social support in a rural community in Zona da Mata, Pernambuco State, Brazil. Transtornos mentais comuns e apoio social: estudo em comunidade rural da Zona da Mata de Pernambuco, Brasil. Cad Saude Publica. 2005;21:73-9.

20. Gonçalves DM, Kapczinski F. Prevalence of mental disorders at a referral center for the Family Health Program in Santa Cruz do Sul, Rio Grande do Sul State, Brazil. Prevalência de transtornos mentais em indivíduos de uma unidade de referência para Programa Saúde da Família em Santa. Cad Saúde Pública. 2008;24:2043-53.

21. Thompson AE, Anisimowicz Y, Miedema B, Hogg W, Wodchis WP, AubreyBassler K. The influence of gender and other patient characteristics on health care-seeking behaviour: a QUALICOPC study. BMC Fam Pr. 2016;17:38.
22. Pinheiro RS, Viacava F, Travassos C, dos Brito AS. Gender, morbidity, access and utilization of health services in Brazil. Gênero, morbidade, acesso e utilização de serviços de saúde no Brasil. Ciênc Saúde Coletiva. 2002;7:687-707.

23. Levorato CD, de Mello LM, da Silva AS, Nunes AA. Factors associated with the demand for health services from a gender-relational perspective. Fatores associados à procura por serviços de saúde numa perspectiva relacional de gênero. Ciênc Saúde Coletiva. 2014;19:1263-74.

24. Smedley BD, Stith $A Y$, Nelson AR. Unequal treatment: confronting racial and ethnic disparities in health care. J Natl Med Assoc. 2003. https://doi. org/10.17226/12875.

25. Boccolini CS, de Souza Junior PRB. Inequities in Healthcare utilization: results of the Brazilian National Health Survey, 2013. Int J Equity Heal. 2016;15:150.

26. de Arruda GO, de Mathias TAF, Marcon SS. Prevalence and factors associated with the use of public health services for adult men. Prevalência e fatores associados à utilização de serviços públicos de saúde por homens adultos. Ciênc Saúde Coletiva. 2017;22:279-90.

27. Joung IM, van der Meer JB, Mackenbach JP. Marital status and health care utilization. Int J Epidemiol. 1995;24:569-75.

28. National Collaborating Centre for Mental Health (UK). Common mental healthd: identification and pathways to care. Leicester: RCPsych; 2011.

\section{Publisher's Note}

Springer Nature remains neutral with regard to jurisdictional claims in published maps and institutional affiliations.
Ready to submit your research? Choose BMC and benefit from:

- fast, convenient online submission

- thorough peer review by experienced researchers in your field

- rapid publication on acceptance

- support for research data, including large and complex data types

- gold Open Access which fosters wider collaboration and increased citations

- maximum visibility for your research: over $100 \mathrm{M}$ website views per year

At BMC, research is always in progress.

Learn more biomedcentral.com/submissions 